Apidologie, 1971, 2 (3), 239-246.

\title{
MANIPULATION PROCEDURES IN THE TECHNIQUE OF INSTRUMENTAL INSEMINATION OF THET QUEEN HONEYBEE \\ APIS MELLIFERA L. (HYMENOPTERA : APIDAE) ${ }^{1}$
}

\author{
João M. F. de CAMARGO * and Lionel S. GONCALVES \\ Departamento de Genética da Faculdade de Medicina de Ribeirão Prêto \\ Ribeirão Prêto, S. P. - Brasil
}

\section{SUMMARY}

In this paper it is discussed the shape of the " genital chamber " of queen honeybees and is presented a modification in the classical technique of instrumental insemination mainly in what refers to the position of the syringe in relation to the genital orifice. The syringe tip is adjusted not directly to the orifice of the genital chamber, but a little ventrally of it.

Results of 50 instrumental inseminations using the new technique are also presented. It should be emphasized that no difference exists, in what technique concerns, in the procedures of instrumental insemination of A.m.adansonii or A.m.ligustica queens.

Data on the number of the days necessary for the first laying and duration of the ovipositional period are also discussed.

\section{INTRODUCTION}

The genital tract of queen honeybee (Apis mellifera L.) has been since some years ago studied by the members of this Department in order to clarify the function of its component structures as an important step to further improvements in the technique of instrumental insemination.

Camargo and Mello (1970) presented in their figure 5 the shape of the

1. This research was carried out with the help of the Fundação de Amparo à Pesquisa do Estado de São Paulo - Brasil.

2. Depto. de Genética da Faculdade de Medicina de Ribeirão Prêto, S.P. - Brasil.

3. Depto. de Biologia da Faculdade de Filosofia, Ciências e Letras de Ribeirão Prêto, S.P. - Brasil. 
genital tract some how different from previous authors. F. Ruttner wrote to the senior author pointing that this will have some importance in instrumental insemination. Actually, Ruttner was right since in the last three years we had introduced a small modification in the position of the syringe tip. Such position differs from the one used in the classical technique of instrumental insemination and can be better ascertained after a previous knowledge of the mentioned paper.

We will make a short discussion specially on the height and length of the " genital chamber " which were the main factors considered in the modifications of the technique of instrumental inseminations.

As to the question dealing on the general shape of the ( genital tract ) it was almost completely answered in the paper we mentioned previously. The height and length of the " genital chamber " changes a little depending upon some factors, among which age and size of the virgin queen play the most important role. It is evident also that we may expect some changes depending on the kind of the liquid used during the dissection and also alterations caused by the fixative employed to undertake the histological studies. According to the fixative used we may also have contractions of the organs and this may alter their original shape. We did not use in our considerations measurements of the genital tract. Besides, the histological preparations did not show the exact shape of the genital organs.

In order to study the " genital chamber », virgin queens were dissected both alive and fixed. The alive ones were dissected in Ringer or glycerine and the fixed ones in $70 \%$ alcohol. The genital structures were stained with methylen blue what makes the observations easier.

30 honeybee queens were dissected $(10 \mathrm{~A}$. m. ligustica, $10 \mathrm{~A}$. m. caucasica and 10 hybrid of adansonii and ligustica). From each subspecies 5 queens were previously Bouin fixed and 5 were dissected alive. The age of the queens ranged from 6 to 8 days old and all of them weighed more than $200 \mathrm{mg}$. These virgin queens were reared by the standard Doolittle methods double graft and allowed to emerge in individual small bottles within an humidified incubator at $34^{\circ} \mathrm{C}$.

All queens dissected presented basically the same main configurations of the genital tract barring small differences which are characteristics of each subspecies. For instance, the adansonii queens have sting chamber smaller than ligustica but, the technique of instrumental insemination used is absolutely the same.

We compared our observations with the ones contained in the excellent paper of Laidlaw (1944). The height and length of the genital chamber of our material are in agreement with the figures 2, 3 and 7 of Laidlaw's paper where the genital tract is showed externally. With respect to the figure 5 there are 
some minor differences. According to Dr. Laidlaw : « from a posterior view the vagina (= genital chamber) is oval. It is flattened antero-posteriorly and is inclined forward at an angle approximately $30^{\circ}$ from the perpendicular (inclination not shown in drawings) " (pag. 435). However, our observations show, that the inclination of the genital chamber in relation to the median oviduct varied between 40 and $90^{\circ}$ being this organ higher dorso ventrally and shorter antero-posteriorly in comparison with figure 5 of Laidlaw (1944) and the genital orifice is placed in a plane higher than the median oviduct.

\section{THE TECHNIQUE}

Based in our own observations we introduced a small modification in the position of the syringe mainly in what concerns its relation with the orifice of the genital chamber.

The drawings were made in order to show schematically the technique of instrumental insemination and they omit some anatomical details. The positions assumed by the tract during the insemination process were drawn by inference (in relative proportion) but the tip of syringe and the organs are in scale.

In figure 1 the terminal portion of the queen abdomen opened by the hooks of the insemination apparatus is shown. In the tip of the syringe it can be seen from end to top : distilled water, mixed with $1 \%$ streptomycin, air, semen, air and Jarycox liquid (Nacl $0,7 \%$, $\mathrm{KCl} 0,25 \%$ in distilled water) or coconut water (CAMARGO, personal communication). The liquid in the end of the syringe is used to avoid drying and consequently the killing of the spermatozoa.

In order to provide an easier description on the technique we will follow the sequence presented by the drawings :

Figure $1-A$ : The correct position of the syringe depends upon the opening of sting chamber and in general the syringe should be tilted between 70 and $80^{\circ}$ in relation to the Laidlaw's insemination apparatus.

The syringe must be pointed to the ventral portion (i. e., in direction to the last sternite) of the bursa copulatrior and the tip must be nearly under the orifice of the genital chamber (= orifice of vagina) as showed in the figure 1-A. The location of this orifice and the valvefold can be easily ascertained by using a small drop of Fast Green solution (Camargo and Gonçalves, 1968). The syringe is adjusted ventrally of the orifice of the genital chamber because the median oviduct is not in the same plane as the orifice but situated nearer to the sternites.

Figure 1-B : After the syringe is in position and in the right angle it is moved backwards to allow the next operation. The genital probe is introduced forcing a little the superior wall of the orifice until the valvefold is overpassed. After this the valvefold is compressed against the ventral portion of the tract while the genital orifice is displaced ventraly in order to receive the syringe. This operation allows the orifice be set in the same plane as the median oviduct, which will enable a good insemination. This procedure will avoid the touching with the tip of the syringe in the membranes which enclose the duct opening of the spermatheca.

Figure 1-C:At the same time the probe compresses the valvefold and the ventral wall of the orifice, the syringe is moved downwards and its introduction is started. The tip of the syringe must go beyond the valvefold and reach the median oviduct.

Figure 1-D : While removing the probe the syringe must be introduced a little more into the median oviduct. The penetration of the syringe into the genital tract varies from 1 to $1,5 \mathrm{~mm}$ depending on the size of the queen and also on the distension or contraction of the genital membranes. The membrane of the genital orifice set perfectly around the tip of the syringe when the position is correct.

In this figure we show the syringe correctly introduced into the genital orifice and the injection of spermatozoa being done. 

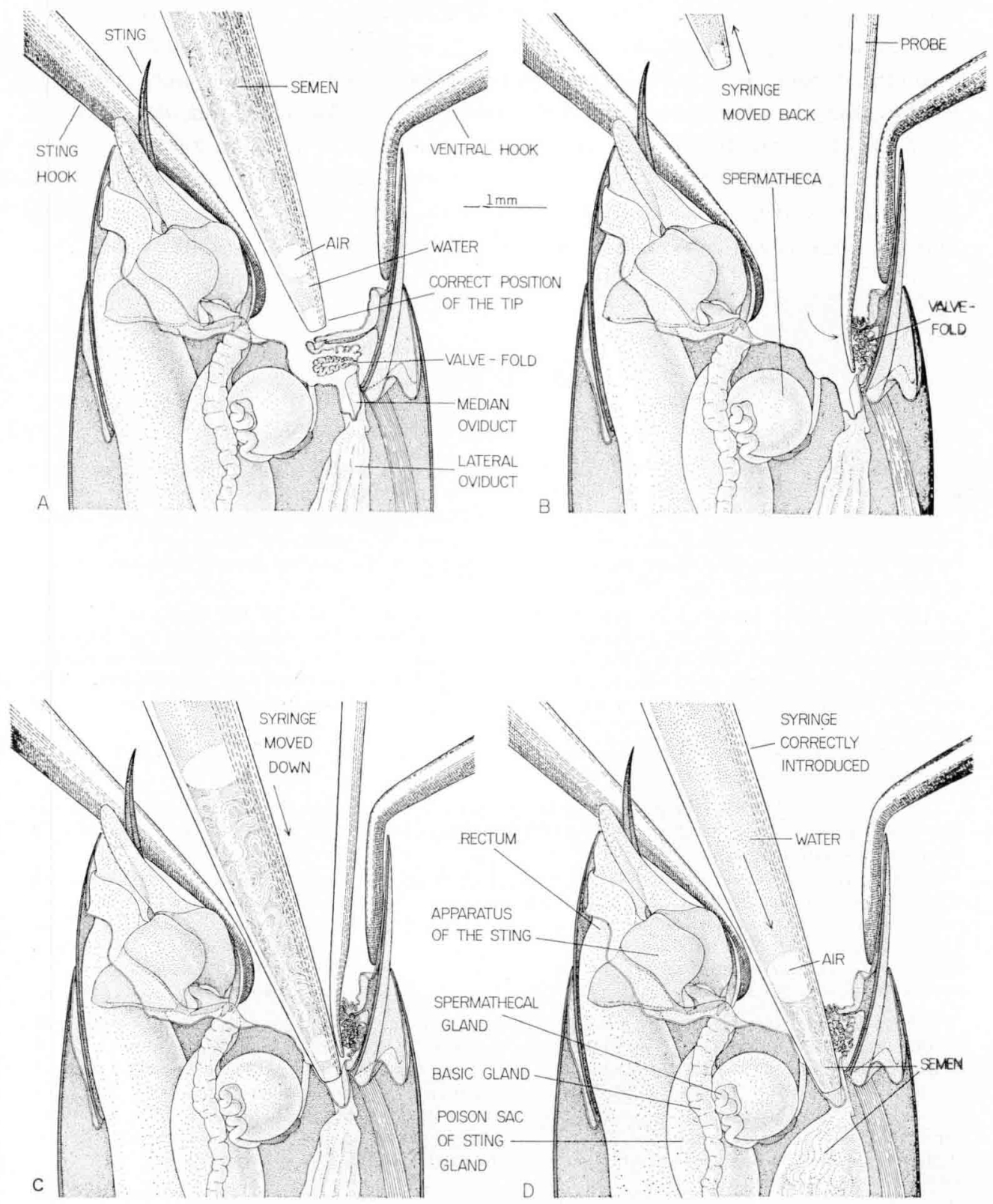

Fig. 1 


\section{RESULTS}

In order to show an application of the technique just mentioned we present here data of a series of queens instrumentaly inseminated (A. m. adansonii and $A . m$. ligustica) by one of us (L.S.G.).

In this Department a success of $95 \%$ in the results was achieved after the introduction of the described method.

The crosses we will discuss were made for another purpose but we are now using their results to justify the employ of the new technique in which italian and specially african queens were used. A few biological characteristics, will also be considered here.

Woyke (1967) showed that the average volume of the spermatheca of a group of 5 virgin queens weighing 207, 189, 172, 144 and $119 \mathrm{mg}$ were 1,23 ; 1,$15 ; 1,00 ; 0,89$ and $0,62 \mathrm{cu} . \mathrm{mm}$ respectively. He also showed that queens with smaller spermatheca had less spermatozoa, independently whether they were naturally or artificially inseminated. Based in this paper virgin queens weighing less than $200 \mathrm{mg}$ were normally eliminated by us.

To discuss here the results obtained with the new technique we selected 50 queens (25 italians and 25 africans) most of them weighing more than $200 \mathrm{mg}$ with the only exception of three queens.

We will consider in this paper the influence of the queen's weight in the starting and duration of egg laying among the races studied.

The 50 queens were inseminated using the technique here mentioned and the crosses were the following : a) 22 adansonii queens inseminated each one with one drone from an hybrid queen (ligustica $\times$ adansonii); b) 16 ligustica queens inseminated each one with one drone from an hybrid queen (ligustica $\times$ adansonii); c) 3 adansonii queens inseminated each one with one drone from an adansonii queen; d) 3 ligustica queens inseminated each one with one drone from an adansonii queen; e) 6 ligustica queens inseminated each one with one drone from a ligustica queen.

All the italian drones and queens were reared from a queen $A$. m. ligustica (hive $n^{\circ} 7$ ) imported from U.S.A. The african drones and queens were reared from a queen $A . m$. adansonii (hive $n^{\circ} 63$ ) free mated. We consider the population of the hive $n^{\circ} 63$ as an african one due its characteristics of fierceness, swarming disposition, strong brood rearing tendency and high honey productivity, which are the characteristics peculiar to the african strains introduced in Brazil in 1.956 (Kerr, 1.967).

All the queens were inseminated usually in its seventh day old and 24 hours later the queens were anaesthetized with carbon dioxide for 3 minutes to hasten the initiation of oviposition. Their wings in one side were clipped to prevent 
TABLE 1. - Queens of A.m.adansonii and A.m.ligustica subspecies instrumentaly inseminated with one drone*.

\begin{tabular}{|c|c|c|c|c|c|c|}
\hline $\begin{array}{c}\text { Queen } \\
\text { Number }\end{array}$ & $\underset{\text { Cross }}{\text { Type of }}$ & $\begin{array}{l}\text { Weigt of } \\
\text { Queen } \\
\text { (mg.) }\end{array}$ & $\begin{array}{c}\text { Date of } \\
\text { Insemination }\end{array}$ & $\begin{array}{c}\text { Date first } \\
\text { laying }\end{array}$ & $\begin{array}{l}\text { Initial } \\
\text { laying } \\
\text { (days) }\end{array}$ & $\begin{array}{c}\text { Ovipositional } \\
\text { period } \\
\text { (months) }\end{array}$ \\
\hline $\begin{array}{r}8-4-68 \\
12-3-68 \\
30-3-68 \\
37-2-68 \\
39-4-68 \\
52-6-68 \\
58-5-68 \\
75-6-68 \\
77-2-68 \\
80-3-68 \\
81-3-68 \\
84-3-68 \\
90-3-68 \\
123-3-68 \\
127-6-68 \\
129-7-68 \\
135-2-68 \\
136-5-68 \\
138-2-68 \\
143-2-68 \\
144-3-68 \\
145-2-68 \\
148-4-68 \\
154-4-68 \\
155-7-68 \\
158-5-68 \\
161-6-68 \\
169-7-68 \\
170-5-68 \\
171-2-68 \\
174-1-68 \\
175-2-68 \\
178-2-68 \\
179-5-68 \\
184-2-68 \\
186-4-68 \\
187-3-68 \\
189-3-68 \\
189-6-68 \\
192-7-68 \\
201-4-68 \\
205-3-68 \\
206-3-68 \\
208-2-68 \\
210-2-68 \\
214-4-68 \\
215-3-68 \\
216-3-68 \\
221-3-68 \\
239-3-68\end{array}$ & $\begin{array}{l}a \\
a \\
e \\
b \\
a \\
b \\
b \\
a \\
a \\
b \\
b \\
b \\
a \\
b \\
a \\
c \\
a \\
b \\
a \\
a \\
e \\
b \\
d \\
e \\
e \\
c \\
a \\
a \\
d \\
a \\
b \\
e \\
b \\
a \\
a \\
b \\
b \\
a \\
c \\
b \\
d \\
e \\
a \\
a \\
a \\
b \\
a \\
b \\
a \\
a\end{array}$ & $\begin{array}{l}240 \\
215 \\
214 \\
190 \\
205 \\
220 \\
205 \\
220 \\
215 \\
210 \\
230 \\
220 \\
200 \\
210 \\
240 \\
220 \\
220 \\
245 \\
195 \\
220 \\
245 \\
210 \\
200 \\
245 \\
228 \\
200 \\
235 \\
210 \\
215 \\
210 \\
225 \\
235 \\
200 \\
220 \\
210 \\
225 \\
210 \\
215 \\
200 \\
215 \\
210 \\
200 \\
220 \\
225 \\
175 \\
200 \\
235 \\
200 \\
220 \\
215\end{array}$ & $\begin{array}{r}4 / 03 / 68 \\
3 / 01 / 68 \\
22 / 01 / 68 \\
27 / 01 / 68 \\
4 / 03 / 68 \\
27 / 01 / 68 \\
16 / 02 / 68 \\
4 / 03 / 68 \\
8 / 11 / 68 \\
25 / 04 / 68 \\
1 / 03 / 68 \\
16 / 02 / 68 \\
8 / 01 / 68 \\
27 / 01 / 68 \\
3 / 01 / 68 \\
30 / 10 / 68 \\
4 / 03 / 68 \\
27 / 01 / 68 \\
8 / 01 / 68 \\
29 / 01 / 68 \\
22 / 01 / 68 \\
8 / 01 / 68 \\
30 / 08 / 68 \\
2 / 01 / 68 \\
2 / 01 / 68 \\
19 / 07 / 68 \\
3 / 01 / 68 \\
4 / 03 / 68 \\
30 / 08 / 68 \\
3 / 01 / 68 \\
27 / 01 / 68 \\
2 / 01 / 68 \\
1 / 03 / 68 \\
29 / 01 / 68 \\
4 / 03 / 68 \\
27 / 01 / 68 \\
27 / 01 / 68 \\
4 / 03 / 68 \\
30 / 09 / 68 \\
1 / 03 / 68 \\
30 / 01 / 68 \\
8 / 01 / 68 \\
4 / 03 / 68 \\
8 / 01 / 68 \\
8 / 01 / 68 \\
16 / 02 / 68 \\
3 / 01 / 68 \\
16 / 02 / 68 \\
4 / 03 / 68 \\
29 / 01 / 68\end{array}$ & $\begin{array}{r}11 / 03 / 68 \\
9 / 01 / 68 \\
30 / 01 / 68 \\
2 / 02 / 68 \\
14 / 03 / 68 \\
2 / 02 / 68 \\
22 / 02 / 68 \\
11 / 03 / 68 \\
15 / 11 / 68 \\
5 / 05 / 68 \\
6 / 03 / 68 \\
28 / 02 / 68 \\
15 / 01 / 68 \\
2 / 02 / 68 \\
9 / 01 / 68 \\
8 / 11 / 68 \\
11 / 03 / 68 \\
2 / 02 / 68 \\
15 / 01 / 68 \\
5 / 02 / 68 \\
30 / 01 / 68 \\
15 / 01 / 68 \\
10 / 09 / 68 \\
9 / 01 / 68 \\
9 / 01 / 68 \\
29 / 07 / 68 \\
9 / 01 / 68 \\
14 / 03 / 68 \\
10 / 09 / 68 \\
9 / 01 / 68 \\
2 / 02 / 68 \\
9 / 01 / 68 \\
10 / 03 / 68 \\
7 / 02 / 68 \\
14 / 03 / 68 \\
2 / 02 / 68 \\
2 / 02 / 68 \\
11 / 03 / 68 \\
12 / 10 / 68 \\
6 / 03 / 68 \\
10 / 09 / 68 \\
15 / 01 / 68 \\
11 / 03 / 68 \\
15 / 01 / 68 \\
15 / 01 / 68 \\
28 / 02 / 68 \\
9 / 01 / 68 \\
21 / 02 / 68 \\
11 / 03 / 68 \\
7 / 02 / 68\end{array}$ & $\begin{array}{r}7 \\
6 \\
8 \\
6 \\
10 \\
6 \\
6 \\
7 \\
7 \\
10 \\
5 \\
12 \\
7 \\
6 \\
6 \\
8 \\
7 \\
6 \\
7 \\
7 \\
8 \\
7 \\
10 \\
7 \\
7 \\
10 \\
6 \\
10 \\
10 \\
6 \\
6 \\
7 \\
9 \\
9 \\
10 \\
6 \\
6 \\
7 \\
12 \\
5 \\
10 \\
7 \\
7 \\
7 \\
7 \\
12 \\
6 \\
5 \\
7 \\
9\end{array}$ & $\begin{array}{l}2 \\
8 \\
5 \\
2 \\
2 \\
6 \\
2 \\
2\end{array}$ \\
\hline
\end{tabular}

Type of Crosses : a - African queen $\mathrm{x}$ drone from hydrib queen (ligustica $\mathbf{x}$ adansonii)

$b$ - Italian queen $x$ drone from hybrid queen (ligustica $x$ adansonii).

$c$ - African queen $x$ african drone.

$d$ - Italian queen $x$ african drone.

$e-$ Italian queen $x$ italian drone.

- Italian strain (A.m.ligustica) and African strain (A.m.adansonii). 
further mating and they were then introduced into a nucleus and there confined by entrance queen excluders.

The results and the data of each cross are presented in Table I. An analysis of such data showed that the 50 queens, weighed in average $215,80 \mathrm{mg}$ and laid in average four months (with range from 2 to 8 months). The 25 italian queens weighed in average $216,40 \mathrm{mg}$ and the 25 african ones weighed in average $215,20 \mathrm{mg}$. Both races showed no difference in the ovipositional period. The range from 2 to 8 months could be attributed to the amount of semen injected in each queen although we didn't control the quantity of semen ${ }^{1}$.

Another interesting result was related with the first laying date. The 50 queens started laying within 5 to 12 days with an average of 7,5 days after the insemination. The italians started egg laying a little before than the african ones but the difference was less than one day. Such difference should not be considered because the inspections to ascertain the start of oviposition were not made in the same hour of the day. This can be responsible for the small difference showed among this two races and the data only suggest that there is not a significant difference in such behaviour.

From the results above presented we can conclude that there is no difference in the technique of instrumental insemination both in adansonii or ligustica queens in spite of the small difference in the shape and size of the queens abdomen in the two races concerned. Nevertheless, we emphasized that both races showed the same internal constitution of the genital tract and the data here discussed ratify the success of the technique of intrumental insemination presented.

Reçu pour publication en mars 1971.

\section{ACKNOWLEDGEMENTS}

We would like to thank Prof. R. Zucchi, Prof. W. E. Kerr and Prof. A. A. Jacquemin for their co-operation and assistance.

\section{RÉSUMÉ}

PRocéduRES DE MANIPUlation DANS LA TECHNiQUe de L'insémination artificielle DE LA Reine D'ABeille Apis mellifica L.

Le tractus génital a été examiné comparativement sur des reines fraîches et fixées appartenant à la race italienne $(A$. m. ligustica) et à la race centre-africaine $(A$. m. adansonii). Ne tenant pas compte de différences mineures (chez $A, m$. adansonii la chambre de l'aiguillon est un peu plus étroite) on peut considérer que la c chambre génitale " présente la même forme

1. We have been successfuly inseminating queens of $A \cdot m$. caucasica but we do not have yet information about the duration of its egg laying. 
dans les deux races et que la technique d'insémination artificielle applicable est, par conséquent, la même.

Les différences dans la forme de la “ chambre génitale » constatées par rapport aux travaux d'autres auteurs proviennent en fait de différences dans l'âge et la taille des reines ainsi que des méthodes de fixation.

La pointe de la seringue ne doit pas être dirigée directement sur l'ouverture vaginale mais au contraire vers un point légèrement plus ventral ( $\mathrm{fig} .1, \mathrm{~A}$ ), de telle sorte qu'elle vienne dans l'axe de l'oviducte médian (fig. 1, C).

50 reines d'A. $m$. ligustica et d'A. m. adansonii ont été inséminées selon cette méthode avec le sperme d'un unique mâle. La réussite fut de $95 \%$. La période de ponte, qui commença en moyenne 7,5 jours après l'insémination, fut en moyenne de 4 mois ( 2 à 8 mois). Aucune différence entre les deux races et leurs hybrides n'a été mise en évidence.

\section{ZUSAMMENFASSUNG}

\section{BEHANDLUNGSVERAhREN IN DER TECHNIK DER KÜNSTLICHEN BESAMUNG} Der BIEnenKönigin Apis mellifica L.

An frischen und fixierten Köninginen der Italienischen Biene (A. m. ligustica) und der Zentralafrikanischen Biene $(A$. $m$. adansonii) wurde vergleichend der Genitaltrakt untersucht. Abgesehen von geringfügigen Unterschieden (bei $A$. $m$. adansonii ist die Stachelkammer etwas enger) ist die Genitalkammer bei beiden Rassen gleich geformt und die Technik der instrumentellen Besamung deshalb identisch.

Unterschiede in der Form der Genitalkammer gegenüber anderen Autoren beruhen auf Unterschieden in Alter und Grösse der Königin und auf verschiedenen Fixierungsmethoden.

Die Spritzenspitze soll nicht direkt auf die Scheidenöffnung, sondern auf einen Punkt etwas ventral von ihr gerichtet sein $(\mathbf{A b b} .1, \mathbf{A})$, damit sie in die Achse des mittleren Eileiters kommt (Abb. 1, C).

50 Königinnen von $A$. m. ligustica und von $A . m$. adansonii wurden nach dieser Methode mit dem Samen von einem einzigen Drohnen besamt. Der Erfolg lag bei $95 \%$. Die Periode der Eiablage, die im Durchschnitt 7,5 Tage nach der Besamung einsetzte, hielt im Durchschnitt 4 Monate (2-8 Monate) an. Unterschiede zwischen den beiden Rassen und ihren Hybriden wurden nicht festgestellt.

\section{RÉFÉRENCES}

Camargo J.M.F. de, Gonçalves L.S., 1968. Note on Techniques for Instrumental Insemination of Queen Honeybee. J. Apic. Res., 7 (3) : 157-161.

Camargo J.M.F. de, Mello M.L.S., 1970. Anatomy and Histology of the Genital Tract, Spermatheca, Spermathecal Duct and Glands of Apis mellifera Queens (Him. : Apidae). Apidologie (4), 351-373.

KerR W.E., 1966-1967. Solução é criar uma raça nova. Coopercotia, Guia Rural, 20-22.

LaIDLAW H.H.Jr., 1944. Artificial insemination of the queen bee (Apis mellifera L.). Morphological basis and results. $J$. Morph., 74 (3), 429-465.

WoYke J., 1967. Rearing conditions and the number of sperm reaching the queens spermatheca. Apimondia XXI Intern. Beekeep. Congress, 84. 


\section{ERRATUM}

In our previous paper : Camargo J. L. F. and M. M. S. Mello - $1970-$ Anatomy and Histology of the Genital Tract, Spermathecal Duct and Glands of Apis mellifica Queens (Hymenoptera : Apidae). Apidologie, I (4) : 351 373 , the micropyle was erroneously placed and indicated at the posterior end of an Apis mellifica egg (Fig. 14, page 367). In spite of such error we still maintain our hypothesis that the valvefold indentations in laying queens may serve to lodge the spermatozoa coming from spermatheca and so preventing its dispersion into the genital tract (page 369). 